\title{
Malignus gastroduodenalis obstrukció endoszkópos palliációja fedetlen enteralis stenttel
}

\author{
Szegedi László dr. - Dandé Gábor dr. - Ágoston Sándor dr. \\ Kovács János dr. - Rácz Ferenc dr. - Vén László dr. \\ Szabolcs-Szatmár-Bereg Megyei Kórházak és Egyetemi Oktatókórház, \\ Jósa András Oktatókórház, I. Belgyógyászat, Nyíregyháza
}

\begin{abstract}
Bevezetés: A malignus gastroduodenalis obstrukció palliatív kezelése enteralis stentekkel hatékony és biztonságos módszer, a palliatív céllal elkészített gastroenterostomia reális alternatívája. Célkitüzés: A szerzők ismertetik a malignus gastroduodenalis obstrukció hátterében fennálló leggyakoribb daganatos betegségeket, a stent kiválasztásának szempontjait, behelyezési technikáját, valamint elemzik a kezelés technikai és klinikai sikerességét, megemlítve a lehetséges komplikációkat. Módszer: 2013. március 1. és 2015. április 9. között 19 esetben történt fedetlen, öntágulós enteralis stentbehelyezés. A 19 beteg közül 6 nő, 13 férfi, átlagéletkoruk 67 év volt. A stentelés indikációját 5 esetben peripyloricus gyomortumor, 1-1 esetben a duodenum, gastroenteralis anastomosis, Vater-papilla és az epehólyag malignus folyamata, 7 esetben pancreas, 3 esetben az epeút tumora képezte. Eredmények: A stentbehelyezés technikai sikeressége 100\%-os volt. A klinikai siker objektivizálása a Gastric Outlet Obstruction Scoring System alapján történt. Következtetések: Az enteralis stentek alkalmazása malignus gastroduodenalis obstrukcióban technikailag jól kivitelezhető, biztonságos módszer, amely látványosan csökkenti a betegség tüneteit, javítja az életminőséget. Orv. Hetil., $2015,156(44), 1778-1781$.
\end{abstract}

Kulcsszavak: enteralis stent, malignus gastroduodenalis obstrukció, stentbehelyezés, duodenumszúkület

\section{Palliative endoscopic treatment of malignant gastroduodenal obstructions with uncovered enteral stents}

Introduction: Palliative treatment of malignant gastroduodenal obstructions with enteral stents is an effective and safe method, and a viable alternative to gastroenterostomy. Aim: The authors present the most common malignancies behind gastroduodenal obstructions, the aspects of stent selections, insertion techniques, technical and clinical success rates, and possible procedure-related complications. Method: Between 1 March, 2013 and 9 April, 2015 nineteen patients were treated with uncovered, self-expandable enteral stents. Out of the 19 patients, 6 were females and 13 males, with an average age of 67 years. Indications of stenting were peripyloric ventricular tumour in five cases, malignancies of the duodenum, gastroenteralis anastomosis, Vater papilla and gallbladder in one case respectively, pancreatic tumor in seven cases and bile duct malignancies in three cases. Results: The technical success rate of stent placement was 100\%. The evaluation of clinical success was analised on the basis of the Gastric Outlet Obstruction Scoring System. Conclusions: The use of enteral stents in malignant gastroduodenal obstructions is a reliable and safe method, which promptly decreases symptoms of the patients and improves their quality of life.

Keywords: enteral stent, malignant gastroduodenal obstruction, stent placement, duodenal stricture

Szegedi, L., Dandé, G., Ágoston, S., Kovács, J., Rácz, F., Vén, L. [Palliative endoscopic treatment of malignant gastroduodenal obstructions with uncovered enteral stents]. Orv. Hetil., 2015, 156(44), 1778-1781.

(Beérkezett: 2015. augusztus 11.; elfogadva: 2015. szeptember 10.) 


\section{Rövidítések}

ERCP = endoszkópos retrográd cholangiopancreatographia; $\mathrm{Fr}=$ French, mértékegység, 1 French $=0,33 \mathrm{~mm}$; GOOSS score $=($ Gastric Outlet Obstruction Scoring System $)$ a gyomorkimenet-elzáródás mértékét meghatározó skála; in = inch, mértékegység, 1 inch $=2,54 \mathrm{~cm} ; \mathrm{PTD}=$ percutan transhepaticus drenázs

A malignus gastroduodenalis obstrukció hátterében leggyakrabban a pancreatobiliaris rendszer - elsősorban a pancreasfej - daganatos elváltozásai, illetve peripyloricus gyomortumorok, valamint a duodenum elsődleges vagy másodlagos daganatos elváltozásai állnak $[1,2,3]$. A klasszikus sebészeti palliáció - gastroenteroanastomosis - mellett vagy helyett hazánkban is egyre több endoszkópos centrumban válik gyakorlattá az enteralis stenttel történő endoszkópos palliáció $[3,4,5]$. A Jósa András Oktatókórház, I. Belgyógyászat Gasztroenterológiáján 2013. március óta végzünk rendszeresen fedetlen enteralis stenttel történő beavatkozásokat inoperábilis malignus gastroduodenalis obstrukcióban.

\section{Módszer}

2013. március 1. és 2015. április 9. között 19 beteg esetében történt enteralis stentbehelyezés. A 19 beteg közül 6 nő és 13 férfi, 67 éves átlagéletkorral. 7 betegben a pancreasfej tumoros folyamata, 5 betegben peripyloricus gyomortumor, 1 betegben a duodenum másodlagos daganatos folyamata, illetve 1 betegben szubtotális gyomorreszekciót követően kialakult malignus anastomosisszúkület képezte a stentelés indikációját. l esetben Vater-papilla-tumornál PTD és enteralis stent, 3 esetben epeúti tumornál choledochus és enteralis stent kombinációjával értünk el eredményt. l esetben inoperábilis cholecystatumoros betegünknél PTD - fémstenttel történő internalizálás -, illetve enteralis stentbehelyezés történt. A betegek táplálkozási képességét az 1. táblázatban feltüntetett kritériumok alapján értékeltük. Beteganyagunkban 19 betegből 10 esetben 1 -es, 6 esetben 2 -es és 3 esetben 0-ás GOOSS-score volt megállapítható. A gastroduodenalis tumoros folyamatot proximalisnak tekintettük, amennyiben a pylorus és a papilla szintje között helyezkedett el, és distalisnak, amennyiben a papilla, illetve a papillaszint alatti területre lokalizálódott.

Stenttípusok, a stentválasztás szempontjai és a stentelés technikai kérdései az alábbiak $[1,6,7]$ :

- öntágulós fedetlen fémstent,

- fedett fémstent [8],

- részlegesen fedett, úgynevezett „big cup” Hanaro DPC-stent [9],

- 60-80-100-120-140 mm hossz- és 18-20-22-24 mm átmérőméretek.

A bevezető rendszer átmérője: 3,33 mm-10 Fr, hoszsza: $2100 \mathrm{~mm}$. A beavatkozáshoz használt vezetődrót 0,035 in [10].
1. táblázat

Gyomorkimenet-elzáródás mértékét meghatározó skála [1, 2, 3, 6] (Gastric Outlet Obstruction Scoring System - GOOSS, Adler és Baron, 2002)

\begin{tabular}{lc}
\hline & GOOSS-score \\
\hline Nincs szájon át történő táplálékfelvétel & 0 \\
Szájon át csak folyadékfelvétel történik & 1 \\
Szájon át csak pépesétel-felvétel történik & 2 \\
Normáldiéta, minimális gyomorresiduum & 3 \\
\hline
\end{tabular}

Gyakorlatunkban a stentválasztás részben a nemzetközi és hazai irodalmi adatok, részben saját nyelőcső- és epeúti stentelés közel 20 éves tapasztalata alapján történt. Tekintettel arra, hogy mind a részlegesen fedett, mind pedig a teljesen fedett fémstentek esetén a migrációs ráta igen magas az irodalmi adatok szerint $(32,2 \%)$ $[6,11]$, fedetlen fémstent használata mellett döntöttünk. Ezen stentek alacsony migrációs rátája mellett döntésünket befolyásolta az a tény is, hogy a fedetlen stent bevezetőrendszere vékonyabb, így technikailag könnyebb és biztonságosabb a stentelés, a Vater-papilla régiójában is használhatók, és bár a stentobstrukció magasabb, mint a fedett stentek esetén $(44,4 \%$ a $3,2 \%$-kal szemben), ennek korrekciója egyszerúbben megoldható, mint a migrációé [6]. A stentek behelyezése terápiás gasztroszkóp munkacsatornáján keresztül vezetődrót segítségével történik endoszkópos kontroll és kiegészítő röntgenátvilágító kontroll alatt. Azokban a betegekben, ahol a malignus duodenalis obstrukciót pancreatobiliaris tumor okozza, szükségesnek tartjuk a preventív choledochusstentelést még abban az esetben is, ha jelentős szúkületre a képalkotó vizsgálatok, a laborvizsgálatok és az ERCP aktuálisan még nem utalnak [12]. Véleményünk szerint az epeutak utólagos stentelése endoszkópos úton az enteralis stenten keresztül technikailag nehezen kivitelezhető, nem biztonságos. Intervenciós radiológiai módszer helyettesítheti ilyen esetekben az endoszkópos beavatkozást (percutan transhepaticus drenázs - külső vagy külső-belső).

\section{Eredmények}

A beavatkozás technikai sikeressége 100\%-os volt, a klinikai sikerességet pedig a Gastric Outlet Obstruction Scoring System alapján jellemeztük $[1,2,3]$. A stentbehelyezést követően a klinikai képben látványos javulás következett be. Az első három napban már minden beteg tudott fogyasztani pépes ételt, a 2-es, 1-es score-ral rendelkezők már a vizsgálatot követő napon. A vizsgálatot követő 5 . napon 15 betegnél 3-as GOOSS-score-t regisztráltunk, 3 esetben pedig 2 -es GOOSS-score-t, 1 beteg nem élte meg az 5 . napot a stentbehelyezést követően. A 7 pancreasfejtumoros betegben 4 esetben történt choledochusstentelés az enteralis stent behelyezését megelőzően, 1 betegben intervenciós radiológiai beavat- 
2. táblázat | Kezelt betegeink adatai kor, nem, beavatkozást indikáló diagnózis, stenosis mértéke, a vizsgálatzáráskor észlelt túlélés alapján

\begin{tabular}{|c|c|c|c|c|c|c|c|}
\hline & $\begin{array}{l}\text { Kor } \\
(\text { év) }\end{array}$ & Nem & Diagnózis & $\begin{array}{l}\text { GOOSS } \\
\text { stent előtt }\end{array}$ & $\begin{array}{c}\text { GOOSS } \\
\text { stent után 1. nap }\end{array}$ & $\begin{array}{c}\text { GOOSS } \\
\text { stent után } 5 \text {. nap }\end{array}$ & $\begin{array}{c}\text { Túlélés } \\
\text { (nap) }\end{array}$ \\
\hline 1. & 37 & Férfi & Tu. recti, met. lgl., sten. duod. pp. inf. tu. & 2 & 3 & 3 & 20 \\
\hline 2. & 46 & Férfi & $\begin{array}{l}\text { St. p. res. ventr. et sten. jejuni pp. } \\
\text { pseudomyxomam peritonei }\end{array}$ & 0 & 2 & 2 & 153 \\
\hline 3. & 64 & Férfi & Tu. ventr., sten. pylori & 1 & 2 & 3 & 74 \\
\hline 4. & 81 & Férfi & Tu. bulbi duod. et pylori ventr. & 1 & 2 & 3 & 9 \\
\hline 5 . & 87 & Nő & Tu. antri vent. & 1 & 2 & 3 & 38 \\
\hline 6. & 53 & Férfi & Tu. capitis panc. propag. ad duod. & 0 & 1 & 2 & 12 \\
\hline 7. & 86 & Férfi & Tu. capitis panc. propag. ad duod. & 2 & 3 & 3 & 32 \\
\hline 8. & 59 & Férfi & Tu. capitis panc. propag. ad duod. & 1 & 2 & 3 & 49 \\
\hline 9. & 53 & Férfi & Tu. capitis panc. propag. ad duod. & 2 & 3 & 3 & 46 \\
\hline 10. & 61 & Férfi & Tu. capitis panc. propag. ad. duod. & 1 & 2 & 3 & 203 \\
\hline 11. & 81 & Férfi & Tu. choledochi, sten. duod. & 1 & 2 & 3 & 48 \\
\hline 12. & 76 & Nő & Sten. duod. pp. tu. pap. Vateri & 2 & 3 & 3 & 19 \\
\hline 13. & 60 & Férfi & Tu. panc. propag. ad duod. & 2 & 3 & 3 & 170 \\
\hline 14. & 82 & Nő & Tu. choledochi., sten. duod. & 2 & 3 & 3 & 57 \\
\hline 15. & 83 & Nô & Tu. choledochi., sten. duod. & 1 & 3 & 3 & 8 \\
\hline 16. & 66 & Nő & Tu. panc., sten. duod. & 1 & 2 & 3 & 226 \\
\hline 17. & 65 & Férfi & Tu. ventr., sten. pylori & 1 & 2 & - & 2 \\
\hline 18. & 80 & Férfi & Tu. ventr., sten. pylori & 0 & 1 & 3 & 42 \\
\hline 19. & 53 & Nó & Tu. cholecystae, sten. duod. & 1 & 2 & 3 & 91 \\
\hline
\end{tabular}

kozás a már behelyezett enteralis stent mellett kialakult elzáródásos sárgaság miatt, illetve 2 betegben korábban hepaticojejunostomia történt (2. táblázat). Külön kiemelnénk annak a betegünknek az esetét, akinél a duodenumstenosis teljes áthidalására két enteralis stentet kellett behelyeznünk stent a stentbe megoldással. Ennél a betegnél mechanikus icterus miatt korábban már choledochusstent-behelyezés is történt. Bár a szakirodalom az egy enteralis stenttel kompletten át nem hidalható szúkület esetén nem egyértelmúen javasolja az ilyen jellegú beavatkozást, a beteg jó általános állapotára és várható hosszabb élettartamára való tekintettel mégis a két stent behelyezése mellett döntöttünk, sikeresen. A peripyloricus tumorok, duodenumtumor, illetve a szubtotális gyomorreszekció tumoros recidívája esetén csak enteralis stenteket használtunk. Beteganyagunkban az átlagos túlélés 68,36 nap (2-226 nap között) volt a követési időszak végéig. A kórházi ápolási napok száma összesen 261 nap, átlagosan 13,73 nap.

A stentbehelyezéssel kapcsolatos lehetséges szövődményeket két csoportra osztottuk. Az első csoportot a leggyakrabban előforduló, klinikai szempontból a legfontosabb két komplikáció, a stentelzáródás és a stentmigráció képezte $[2,3,6,13]$. Betegeink követése során stentmigrációra utaló jelet nem észleltünk. A stentelzáródás tumorbenövés miatt egy esetben fordult elő. A második csoportba tartozó komplikációk közül, mint perforáció, vérzés, biliaris problémák, hasi fájdalom, az utóbbi többször előfordult, amely tüneti terápia mellett megszûnt. 1 esetben marginális fekély alakult ki a stent proximális szélénél, amely konzervatív terápiára meggyógyult. A stenttartósság hosszabbnak bizonyult, mint a várható túlélés. Ezt a nemzetközi irodalmi adatok is alátámasztják, amelyek alapján a stenttartósságot 190385 nap közöttinek, az átlagos túlélést pedig 49-182 nap közöttinek találták $[2,3,4]$.

\section{Megbeszélés}

Összefoglalásunk alapján az ismertetett módon nagy biztonsággal, minimális invazivitással, hatékonyan segíthetünk szúkületet okozó, malignus gastrointestinalis megbetegedésben szenvedő pácienseinknek. A technikai sikeresség mértéke tanulmányunkban 100\%-os, amely irodalmi adatok alapján 95-100\% közé esett $[3,7,10$, 11], a beavatkozást követő GOOSS-score legalább 1 értékü növekedése vizsgálatainkban 100\%, az irodalomban 52 és $100 \%$ közé tették $[2,3,4,7,10,11]$.

Egy metaanalízisben a nyílt gastrojejunostomiánál az enteralis stentbeültetés nagyobb eséllyel, rövidebb idő alatt növelte a tápláléktolerálhatóságot, kevesebb beavatkozás utáni ápolási idővel, egyező szövődmény- és mortalitási aránnyal [14]. 
A malignus gastroduodenalis obstrukció endoszkópos palliációja enteralis stentekkel technikailag jól kivitelezhető, hatékony, megbízható eljárás, amely a sebészeti palliáció reális alternatívája $[2,3,13,14]$.

Anyagi támogatás: A közlemény megírása anyagi támogatásban nem részesült.

Szerzői munkamegosztás: Sz. L.: Vizsgálat, statisztika, szerkesztés. D. G.: Szövegírás, szerkesztés. R. F., K. J., Á. S., V. L.: Betegek kezelése, statisztika. A cikk végleges változatát valamennyi szerző elolvasta és jóváhagyta.

Érdekeltségek: A szerzőknek nincsenek érdekeltségeik.

\section{Irodalom}

[1] Moura, E. G., Ferreira, F. C., Cheng, S., et al.: Duodenal stenting for malignant gastric outlet obstruction: prospective study. World J. Gastroenterol., 2012, 18(9), 938-943.

[2] Mansoor, H., Yusuf, M. A.: Outcomes of endoscopic pyloric stenting in malignant gastric outlet obstruction: a retrospective study. BMC Res. Notes, 2013, 6, 280.

[3] Piesman, M., Kozarek, R. A., Brandabur, J. J., et al.: Improved oral intake after palliative duodenal stenting for malignant obstruction: a prospective multicenter clinical trial. Am. J. Gastroenterol., 2009, 104(10), 2404-2411.

[4] Khashab, M., Alawad, A. S., Shin, E. J., et al.: Enteral stenting versus gastrojejunostomy for palliation of malignant gastric outlet obstruction. Surg. Endosc., 2013, 27(6), 2068-2075.

[5] Maetani, I., Tada, T., Ukita, T., et al.: Comparison of duodenal stent placement with surgical gastrojejunostomy for palliation in patients with duodenal obstructions caused by pancreaticobiliary malignancies. Endoscopy, 2004, 36(1), 73-78.

[6] Kozarek, R., Baron, T. H., Song, H. Y. (eds.): Self-expandable stents in the gastrointestinal tract. Springer Science, New York, 2013.

[7] Varadarajulu, S., Banerjee, S. Barth, B., et al.: Enteral stents. Gastrointest. Endosc., 2011, 74(3), 455-464.

[8] Pauli, E. M., Schomisch, S. J., Blatnik, J. A., et al.: A novel overthe-scope deployment method for enteral stent placement. Surg. Endosc., 2013, 27(4), 1410-1411.

[9] Van den Berg, M. W., Walter, D., Vleggaar, F. P., et al.: High proximal migration rate of a partially covered "big cup" duodenal stent in patients with malignant gastric outlet obstruction. Endoscopy, 2014, 46(2), 158-161.

[10] Chan, J., Hilden, K., Fang, J., et al.: Duodenal and colonic stent placement with 0.025 " and 0.035 " guidewires is equally safe and effective. Dig. Dis. Sci., 2012, 57(3), 726-731.

[11] Isayama, H., Sasaki, T., Nakai, Y., et al.: Management of malignant gastric outlet obstruction with a modified triple-layer covered metal stent. Gastrointest. Endosc., 2012, 75(4), 757-763.

[12] Pan, H., Liang, Z., Yin, T. S., et al.: Hepato-biliary-enteric stent drainage as palliative treatment for proximal malignant obstructive jaundice. Med. Oncol., 2014, 31(3), 853. doi: 10.1007/ s12032-014-0853-3.

[13] Lowe, A. S., Beckett, C. G., Jowett, S., et al.: Self-expandable metal stent placement for the palliation of malignant gastroduodenal obstruction: experience in a large, single, UK centre. Clin. Radiol., 2007, 62(8), 738-744.

[14] Ly, J., O'Grady, G., Mittal, A., et al.: A systematic review of methods to palliate malignant gastric outlet obstruction. Surg. Endosc., 2010, 24(2), 290-297.

(Szegedi László dr., Nyíregyháza, Szent István u. 68., 4400 e-mail: dr.szegedi.laszlo@josa.hu)

\section{Eladó praxis}

Veszprém belvárosi, új építésű rendelöben müködő, felnőtt háziorvosi körzet praxisjoga eladó.

Kártyaszám: 1370, alkalmazott egy fö, havi finanszírozás 1 M Ft.

Érdeklődni: +36-30-526-1990. 